\title{
Timing of sexual receptivity and the release of gonadotrophins during puberty in female rats
}

\author{
K. Hashizume and K. Ōhashi \\ Center of Laboratory Animal Science, National Defense Medical College, Tokorozawa, \\ Saitama 359, Japan
}

\begin{abstract}
Summary. In about $60 \%$ of rats that were paired with fertile males before vaginal opening, vaginal opening occurred between 15:00 and 21:00 h under controlled lighting conditions (lights on $06: 00-18: 00 \mathrm{~h}$ ). No rats mated before $12: 00 \mathrm{~h}$ or after $03: 00 \mathrm{~h}$. Most of the rats (52/82) mated within $3 \mathrm{~h}$ after vaginal opening. About $90 \%$ of the rats that were paired with fertile males before vaginal opening mated and most conceived. Serum LH and FSH levels rose from $14: 00 \mathrm{~h}$ to a peak at 18:00 h, whereas hypothalamic LHRH content suddenly decreased by 18:00 h.

This study shows that the timing of sexual receptivity, ovulation and the release of gonadotrophins during puberty are similar to those at pro-oestrus in adult rats and suggest that the diurnal rhythm of hormonal changes plays an important role in timing of the first oestrus.
\end{abstract}

\section{Introduction}

In female rats, the first sexual receptivity and ovulation occurs close to the time of vaginal opening (Blandau \& Money, 1943). Many investigators have studied the onset of puberty in rats and have shown a relationship between vaginal opening and gonadotrophin release (Ramirez, 1973). According to Nelson, Cullin \& Hoffmann (1978) and Ramaley (1979), vaginal opening is useful for the determination of puberty in rats but does not always correspond to the time of the first oestrus.

This study was performed to clarify the timing of vaginal opening, sexual receptivity, ovulation and gonadotrophin release at the first oestrus in female rats.

\section{Materials and Methods}

Animals. Wistar-Imamichi strain rats inbred at our centre were used. They were housed in a room with controlled temperature $\left(23 \pm 2^{\circ} \mathrm{C}\right.$ ), humidity $(40-60 \%)$ and lighting (lights on $06: 00-18: 00$ h). They received dry pellets (CE-2, CLEA, Japan) and tap water ad libitum. All females were weaned at Day 21 or 22 of age (Day $0=$ day of birth).

Detection of sexual receptivity. Sexual receptivity in 82 females was checked every $3 \mathrm{~h}$ from $09: 00 \mathrm{~h}$ on Days 34 to 38 . Two immature females were caged with two fertile males. The first time a copulation plug or spermatozoa were found was designated the time of sexual receptivity $(0 \mathrm{~h})$. Of these females 35 were killed at 2-h intervals for hormone determination from 18:00 h. In another group, 117 females were checked at $09: 00,12: 00,15: 00$ and 18:00 h every day from Days 31 to 42 for spontaneous vaginal opening.

Reproductive performance of pubertal females. In another examination, 113 immature females were caged with fertile males ( 2 females and 2 males) before vaginal opening on Day 33 of age; 92 which showed oestrus at vaginal opening were examined for fertility. Another 47 females, which 
were checked for vaginal opening every $3 \mathrm{~h}$ from $09: 00 \mathrm{~h}$ on Days 33 to 38 , were caged with fertile males just after vaginal opening. Both groups were examined at $09: 00 \mathrm{~h}$ every morning. The day of detection of a plug or spermatozoa was designated Day 1 of pregnancy. Most of the mated rats in both groups (47 and 18) were killed on Days 14-22 of pregnancy, and the number of implantation sites was counted.

Collection of sera and hypothalamic samples. After vaginal opening accompanied by sexual receptivity, 35 rats were killed at 18:00, 20:00, 22:00, 24:00,02:00, $04: 00$ and $06: 00 \mathrm{~h}$ by decapitation. There were few rats in which the vagina opened before $18: 00 \mathrm{~h}$. Therefore, immature females with closed vaginas were selected at random from 10:00-16:00 h based on the uterine weight (over $150 \mathrm{mg}$ ) and vaginal pro-oestrus (the vagina was artificially opened). Sera were collected and stored at $-20^{\circ} \mathrm{C}$ until assayed for hormones. Immediately after decapitation, the preoptic and hypothalamic areas (about $20 \mathrm{mg}$ ) were removed (Glowinski \& Iversen, 1966) and boiled in $2 \mathrm{ml} 0 \cdot 1 \mathrm{~N}$-acetic acid for $10 \mathrm{~min}$. They were then homogenized in $5 \mathrm{ml}$ acetic acid solution, and frozen and thawed twice. After centrifugation at $3000 \mathrm{~g}$ for $30 \mathrm{~min}$ at $4^{\circ} \mathrm{C}$, the supernatants were stored at $-20^{\circ} \mathrm{C}$ until assayed for LHRH.

Radioimmunoassay of hormones. Serum LH and FSH were determined according to the directions provided with the NIAMDD rat radioimmunoassay kit. The antisera used were antirLH-S6 and anti-rFSH-S11. Preparations used for iodination were NIADDK-rLH-I5 and NIAMDD-rFSH-I5. Results were expressed as ng equiv. RP-1/ml serum. LHRH content in the hypothalamus was determined by a double-antibody radioimmunoassay system, which was developed by Hasegawa, Miyamoto, Yazaki \& Igarashi (1981), and expressed in terms (ng/hypothalamus) of synthetic LHRH (Abbott, 26-306AL). Samples were assayed in duplicate. The intra-assay coefficients were $4.0 \%$ for LH, $5 \cdot 1 \%$ for FSH and $2 \cdot 8 \%$ for LHRH, and the lower limits of assay for LH, FSH and LHRH were $1.3 \mathrm{ng}, 10 \mathrm{ng}$ and $40 \mathrm{pg}$ per tube, respectively.

Statistical analysis. Statistical differences were assessed using Student's $t$ test.

\section{Results}

\section{Timing of vaginal opening}

Spontaneous vaginal opening occurred from Day 31 to 42 of age (means \pm s.d., $36 \cdot 6 \pm 2 \cdot 7$ days, $\mathbf{N}=117$ ). The numbers of females exhibiting vaginal opening with respect to the time of day, irrespective of the day of vaginal opening, were: $80 / 117$ at $09: 00 \mathrm{~h}, 8 / 117$ at $12: 00 \mathrm{~h}, 9 / 117$ at $15: 00 \mathrm{~h}$ and $20 / 117$ at $18: 00 \mathrm{~h}$.

In rats that were paired with males before vaginal opening, the day of vaginal opening (mean \pm s.d.) was $36 \cdot 1 \pm 1 \cdot 1(\mathrm{~N}=82)$, with 2 rats showing opening at $03: 00 \mathrm{~h}, 1$ at $06: 00 \mathrm{~h}, 3$ at $09: 00 \mathrm{~h}, 12$ at $12: 00 \mathrm{~h}, 7$ at $15: 00 \mathrm{~h}, 29$ at $18: 00 \mathrm{~h}, 23$ at $21: 00 \mathrm{~h}$ and 5 at $24: 00 \mathrm{~h}$ (Text-fig. 1).

\section{Mating and ovulation}

As shown in Text-fig. 1, in 70 of the 82 females that were paired with males before vaginal opening, mating occurred within $60 \mathrm{~h}$ after vaginal opening, i.e. 33 mated at opening, 19 mated by 3 $\mathrm{h}$ and the remaining 18 mated by $60 \mathrm{~h}$. The others (12) did not mate until $72 \mathrm{~h}$. According to the hour of the day, no rats mated before $12: 00$ or after $03: 00 \mathrm{~h}$. The number of mated rats per total number mated was $6 / 70$ at $15: 00 \mathrm{~h}, 25 / 70$ at $18: 00 \mathrm{~h}, 27 / 70$ at $21: 00 \mathrm{~h}, 11 / 70$ at $24: 00 \mathrm{~h}$ and $1 / 70$ at $03: 00 \mathrm{~h}$.

In 4 of the 5 rats examined at $24: 00 \mathrm{~h}$, ovulation had occurred during the first oestrus and after that all females ovulated $(5 / 5,5 / 5$ and $5 / 5$ at $02: 00,04: 00$ and $06: 00 \mathrm{~h}$, respectively). The mean numbers of eggs ovulated per rat were $12.0 \pm 0.8,13.2 \pm 1.0,11.6 \pm 0.8$ and $12.0 \pm 1.4$, respectively. 


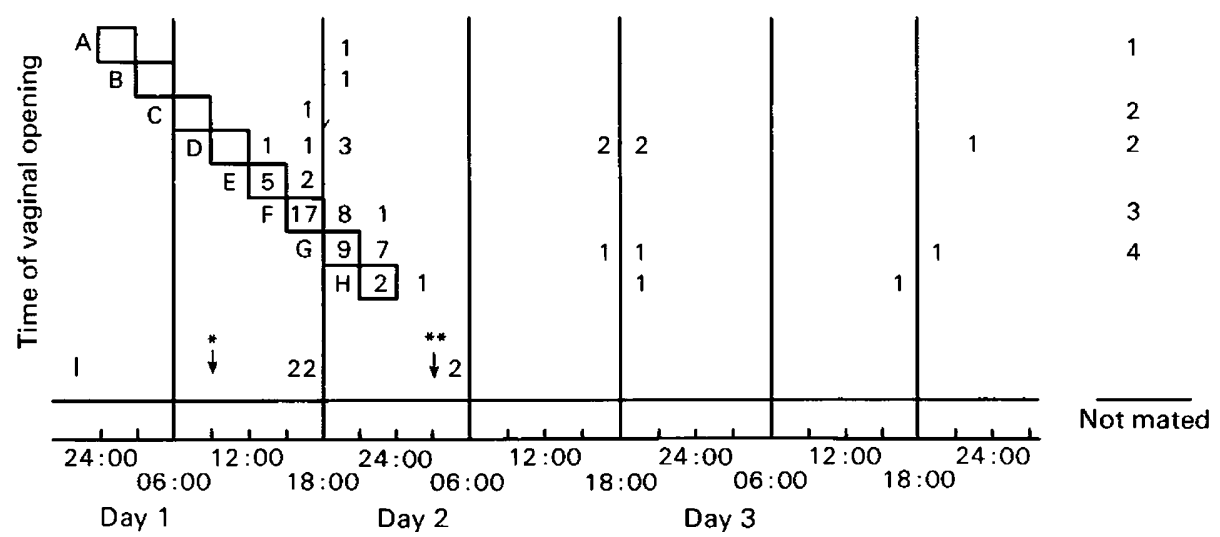

Day after vaginal opening

Text-fig. 1. Time of mating after vaginal opening in rats. Boxes indicate the period of vaginal opening for Groups A-H in 3-h intervals. Numbers indicate the numbers of rats mated during every 3-h interval. Group I indicates the period of sexual receptivity for adult rats, i.e. when 22 adult females were caged with males at $09: 00 \mathrm{~h}\left(\downarrow^{*}\right)$ on the day of pro-oestrus, all rats mated by $18: 00 \mathrm{~h}$ in the same day. Also, $2 / 7$ females that were caged with males at $03: 00 \mathrm{~h}\left(\downarrow^{* *}\right)$ on the day of oestrus mated by $06: 00 \mathrm{~h}$. Not mated represents the number of rats which did not mate within $72 \mathrm{~h}$ after vaginal opening in each group.

In a different experiment, of 92 rats that were paired with males before vaginal opening showed vaginal oestrus, 80 mated within 2 days. Only 47 of these were killed for examination; 39 had conceived and the mean number of implantation sites was $12 \cdot 1 \pm 1 \cdot 7$. However, only 18 of the 40 rats that were paired with males after vaginal opening mated within 3 days. Of this 18,16 had conceived and there were $11.0 \pm 1.2$ implantation sites.

\section{Serum LH, FSH and hypothalamic LHRH content}

$\mathrm{LH}$ and FSH values began to rise at $14: 00 \mathrm{~h}$ and reached the maximum at $18: 00 \mathrm{~h}$. LH returned to basal levels at $24: 00 \mathrm{~h}$, but FSH was still high by $06: 00 \mathrm{~h}$ the following day (Table 1).

LHRH content was $2 \cdot 4 \mathrm{ng} / \mathrm{hyp}$ othalamus at $16: 00 \mathrm{~h}$, but this then fell at $18: 00 \mathrm{~h}(1.5 \mathrm{ng})$ and remained at this low level (Table 1).

Table 1. Changes in serum LH, FSH and hypothalamic LHRH content shortly before and after first oestrus

\begin{tabular}{ccccc}
\hline $\begin{array}{c}\text { Time of } \\
\text { day }(\mathrm{h})\end{array}$ & $\begin{array}{c}\text { No. of } \\
\text { rats }\end{array}$ & $\begin{array}{c}\text { LHRH } \\
\text { (ng/hypothalamus) }\end{array}$ & $\begin{array}{c}\text { LH } \\
(\mathrm{ng} / \mathrm{ml})\end{array}$ & $\begin{array}{c}\text { FSH } \\
(\mathrm{ng} / \mathrm{ml})\end{array}$ \\
\hline $10: 00$ & 8 & $2 \cdot 2 \pm 0 \cdot 3$ & $33 \cdot 8 \pm 11 \cdot 6 \S$ & $144 \cdot 0 \pm 16 \cdot 7$ \\
$12: 00$ & 7 & $2 \cdot 4 \pm 0 \cdot 2$ & $56 \cdot 5 \pm 5 \cdot 9$ & $139 \cdot 3 \pm 15 \cdot 0$ \\
$14: 00$ & 9 & $2 \cdot 3 \pm 0 \cdot 3$ & $554 \cdot 2 \pm 266 \cdot 4$ & $343 \cdot 2 \pm 144 \cdot 7$ \\
$16: 00$ & 10 & $2 \cdot 4 \pm 0 \cdot 2$ & $675 \cdot 7 \pm 217 \cdot 4^{* *}$ & $610 \cdot 4 \pm 190 \cdot 3^{*}$ \\
$18: 00$ & 5 & $1 \cdot 5 \pm 0 \cdot 2 \ddagger$ & $702 \cdot 1 \pm 189 \cdot 1^{* *}$ & $849 \cdot 7 \pm 91 \cdot 7^{* *}$ \\
$20: 00$ & 5 & $1 \cdot 6 \pm 0 \cdot 2 \dagger$ & $221 \cdot 9 \pm 39 \cdot 9^{* *}$ & $766 \cdot 8 \pm 61 \cdot 6^{* * *}$ \\
$22: 00$ & 5 & $1 \cdot 5 \pm 0 \cdot 1 \ddagger$ & $176 \cdot 1 \pm 39 \cdot 1^{* *}$ & $774 \cdot 0 \pm 34 \cdot 7^{* *}$ \\
$24: 00$ & 5 & $1 \cdot 7 \pm 0 \cdot 1 \ddagger$ & $34 \cdot 1 \pm 12 \cdot 8$ & $698 \cdot 5 \pm 64 \cdot 4^{* *}$ \\
$02: 00$ & 5 & $1 \cdot 1 \pm 0 \cdot 1 \ddagger$ & $26 \cdot 5 \pm 6 \cdot 5$ & $505.5 \pm 99 \cdot 9^{* *}$ \\
$04: 00$ & 5 & $1 \cdot 4 \pm 0 \cdot 2 \ddagger$ & $18 \cdot 8 \pm 2 \cdot 9$ & $554 \cdot 5 \pm 20 \cdot 8^{* *}$ \\
$06: 00$ & 5 & $1 \cdot 4 \pm 0 \cdot 2 \ddagger$ & $12 \cdot 5 \pm 1 \cdot 0$ & $388 \cdot 8 \pm 45 \cdot 0^{* *}$ \\
\hline
\end{tabular}

Values are mean \pm s.e.m.

$\S$ In 6 rats values were detectable but in 2 they were not $(n=6)$.

Significantly different from the value for $10: 00 \mathrm{~h},{ }^{*} P<0.05,{ }^{* *} P<0.01$.

Significantly different from the value for 14:00 h, $\dagger P<0.05$, $\ddagger P<0.01$. 


\section{Discussion}

The present study has demonstrated that the timing of vaginal opening, sexual receptivity and ovulation were closely related to the diurnal changes in hormones. These findings are similar to those reported for adult pro-oestrous rats (Nequin, Alvarez \& Schwartz, 1975).

Mating occurred from $12: 00$ to $03: 00 \mathrm{~h}$. This period was consistent with that found by Blandau \& Money (1943), but there are some discrepancies which seem to be related to the difference in the method used to assess sexual receptivity. The difference in the distribution of the number of vaginal openings in rats based on the time of day between the spontaneous and paired groups confirmed these discrepancies. These findings also imply that sexual receptivity begins before the complete perforation of the vagina.

The changes in gonadotrophins during puberty have been studied by several investigators (Meijs-Roelofs, Uilenbroek, DeGreef, DeJong \& Kramer, 1975; Ojeda, Wheaton, Jameson \& McCann, 1976; Dussault, Walker, Dubois \& Labrie, 1977; Sarkar \& Fink, 1979), but the relationship between the timing of vaginal opening, mating and the changes in gonadotrophins is not clear. Chronological changes in these elements are basically similar to those of adults in prooestrus except for LHRH (Daane \& Parlow, 1971; Butcher, Collins \& Fugo, 1974; Araki, Ferin, Zimmerman \& Vande-Wiele, 1975; Nequin et al., 1975; Chiappa \& Fink, 1977). LHRH content in the hypothalamus after $\mathrm{LH}$ release during the first oestrus was still low compared with that in adult rats. This discrepancy may be related to differences in rates of synthesis of LHRH (Ramirez \& Sawyer, 1966; Ojeda et al., 1976; Sarkar \& Fink, 1979; White \& Ojeda, 1981; Advis, Krause \& McKelvy, 1982).

Compared to cyclic rats, ovulation at first oestrus seems to occur slightly earlier, and the "critical period" for the release of gonadotrophins seems to be wider.

LHRH may play an important role in the initiation of vaginal opening (Sakuma \& Pfaff, 1980), because the release of LHRH appears to be associated with opening of the vagina. However, the timing of vaginal opening may be influenced by the diurnal rhythm of endocrine changes during the prepubertal period (Döcke \& Dörner, 1974; Firlit \& Schwartz, 1977; Ronnekleiv, Ojeda \& McCann, 1978; Kraulis, Naish, Gravenor \& Ruf, 1981).

Most of the rats mated during the first oestrus conceived. This finding coincides with other reports (Blandau \& Money, 1943; Miller \& Armstrong, 1981), but not with that of Advis \& Ramirez (1977). Vaginal opening and sexual receptivity occur within a short period, and mating rates are therefore related to the time at which the female rats are paired with males. These results show that pubertal females have the same reproductive ability as adults, but the continuation of pregnancy and fetal development in pubertal rats remains to be studied.

We thank Professor Dr M. Igarashi and Dr Y. Hasegawa of Department of Obstetrics and Gynecology, Gumma University, for help with the radioimmunoassay, and Dr Salvatore Raiti and the National Pituitary Agency, NIAMDD, for the radioimmunoassay materials.

\section{References}

Advis, J.P. \& Ramirez, V.D. (1977) Plasma levels of LH and FSH in female rats with precocious puberty induced by hypothalamic lesions. Biol. Reprod. 17, 3I3-320.

Advis, J.P., Krause, J.E. \& McKelvy, J.F. (1982) Luteinizing hormone-releasing hormone peptidase activities in discrete hypothalamic regions and anterior pituitary of the rat: apparent regulation during the prepubertal period and first estrous cycle at puberty. Endocrinology 110, 1238-1245.
Araki, S., Ferin, M., Zimmerman, E.A. \& Vande-Wiele, R.L. (1975) Ovarian modulation of immunoreactive gonadotropin-releasing hormone $(\mathrm{Gn}-\mathrm{RH})$ in the rat brain: evidence for a differential effect on the anterior and mid-hypothalamus. Endocrinology 96, 644-650.

Blandau, R.J. \& Money, W.L. (1943) The attainment of sexual maturity in the female albino rat as determined by the copulatory response. Anat. Rec. 86, 197215. 
Butcher, R.L., Collins, W.E. \& Fugo, N.W. (1974) Plasma concentration of LH, FSH, prolactin, progesterone and estradiol-17 7 throughout the 4-day estrous cycle of the rat. Endocrinology 94, 1704-1708.

Chiappa, S.A. \& Fink, G. (1977) Hypothalamic luteinizing hormone releasing factor and corticotrophin releasing activity in relation to pituitary and plasma hormone levels in male and female rats. J. Endocr. 72, 195-210.

Daane, T.A. \& Parlow, A.F. (1971) Periovulatory patterns of rat serum follicle stimulating hormone and luteinizing hormone during the normal estrous cycle: effects of pentobarbital. Endocrinology 88, $653-663$.

Döcke, F. \& Dörner, G. (1974) Oestrogen and the control of gonadotrophin secretion in the immature rat. $J$. Endocr. 63, 285-298.

Dussault, J.H., Walker, P., Dubois, J.D. \& Labrie, F. (1977) The development of the hypothalamopituitary axis in the neonatal rat: sexual maturation in male and female rats as assessed by hypothalamic LHRH and pituitary and serum $\mathrm{LH}$ and FSH concentration. Can. J. Physiol. Pharmac. 55, 1091-1097.

Firlit, M.G. \& Schwartz, N.B. (1977) Uncoupling of vaginal opening and the first ovulation. An indication of an alteration in the pituitary-gonadal axis. Biol. Reprod. 16, 441-444.

Glowinski, J. \& Iversen, L.L. (1966) Regional studies of catecholamines in the rat brain. I. The disposition of $\left[{ }^{3} \mathrm{H}\right]$ norepinephrine, $\left[{ }^{3} \mathrm{H}\right]$ dopamine and $\left[{ }^{3} \mathrm{H}\right] \mathrm{DOPA}$ in various regions of the brain. J. Neurochem. 13, 655 669.

Hasegawa, Y., Miyamoto, K., Yazaki, C. \& Igarashi, M. (1981) Regulation of the second surge of folliclestimulating hormone; effects of antiluteinizing hormone-releasing hormone serum and pentobarbital. Endocrinology 109, 130-135.

Kraulis, I., Naish, S.J., Gravenor, D. \& Ruf, K.B. (1981) $5 \alpha$-Androstane-3 $\alpha, 17 \beta$-diol: inhibitor of sexual maturation in the female rat. Biol. Reprod. 2A, 445-453.

Meijs-Roelofs, H.M.A., Uilenbroek, J.Th.J., DeGreef, W.J., DeJong, F.H. \& Kramer, P. (1975) Gonadotrophin and steroid levels around the time of first ovulation in the rat. $J$. Endocr. 67, 275-282.
Miller, B.G. \& Armstrong, D.T. (1981) Superovulatory doses of Pregnant Mare Serum Gondaotropin cause delayed implantation and infertility in immature rats. Biol. Reprod. 25, 253-260.

Nelson, M.L., Cullin, A.M. \& Hoffmann, J.C. (1978) Circadian rhythms of serum estradiol and corticosterone and related organ weight changes in the prepubertal female rat. Biol. Reprod. 18, 125-131.

Nequin, L.G., Alvarez, J. \& Schwartz, N.B. (1975) Steroid control of gonadotropin release. J. Steroid Biochem. 6, 1007-1012.

Ojeda, S.R., Wheaton, J.E., Jameson, H.E. \& McCann, S.M. (1976) The onset of puberty in the female rat: changes in plasma prolactin, gonadotropins, luteinizing hormone-releasing hormone (LHRH) and hypothalamic LHRH content. Endocrinology 98, 630-638.

Ramaley, J.A. (1979) Development of gonadotropin regulation in the prepubertal mammal. Biol. Reprod. 20, 1-31.

Ramirez, V.D. (1973) Endocrinology of puberty. In Handbook of Physiology, Endocrinology II, part 1, pp. 1-29. Ed. R. O. Greep. American Physiological Society, Washington, D.C.

Ramirez, V.D. \& Sawyer, C.H. (1966) Changes in hypothalamic luteinizing hormone releasing factor (LHRF) in the female rat during puberty. Endocrinology 78, 958-964.

Ronnekleiv, O.K., Ojeda, S.R. \& McCann, S.M. (1978) Undernutrition, puberty and the development of estrogen positive feedback in the female rat. Biol. Reprod. 19, 414-424.

Sakuma, Y. \& Pfaff, D.W. (1980) LH-RH in the mesencephalic central grey can potentiate lordosis reflex of female rats. Nature, Lond. 283, 566-567.

Sarkar, D.K. \& Fink, G. (1979) Mechanism of the first spontaneous gonadotrophin surge and that induced by Pregnant Mare Serum and effects of neonatal androgen in rats. $J$. Endocr. 83, 339-354.

White, S.S. \& Ojeda, S.R. (1981) Pituitary LHRH receptors during puberty in the female rat: is the proestrous decline in receptor content due to occupancy? Endocrinology 111, 353-355.

Received 3 January 1984 